\title{
Dominant Northern Hemisphere climate control over millennial-scale glacial sea-level variability
}

\author{
Helge W. Arz ${ }^{\mathrm{a}, *, 1}$, Frank Lamy ${ }^{\mathrm{a}, 1}$, Andrey Ganopolski ${ }^{\mathrm{b}}$, Norbert Nowaczyk ${ }^{\mathrm{a}}$, Jürgen Pätzold ${ }^{\mathrm{c}}$

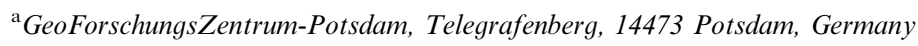 \\ ${ }^{\mathrm{b}}$ Potsdam-Institute for Climate Impact Research, Telegrafenberg, 14473 Potsdam, Germany \\ ${ }^{\mathrm{c}}$ Research Center for Ocean Margins, University Bremen, Klagenfurter Strasse, 28359 Bremen, Germany
}

Received 9 January 2006; received in revised form 11 July 2006; accepted 18 July 2006

\begin{abstract}
Based on a radiocarbon and paleomagnetically dated sediment record from the northern Red Sea and the exceptional sensitivity of the regional changes in the oxygen isotope composition of sea water to the sea-level-dependent water exchange with the Indian Ocean, we provide a new global sea-level reconstruction spanning the last glacial period. The sea-level record has been extracted from the temperature-corrected benthic stable oxygen isotopes using coral-based sea-level data as constraints for the sea-level/oxygen isotope relationship. Although, the general features of this millennial-scale sea-level records have strong similarities to the rather symmetric and gradual Southern Hemisphere climate patterns, we observe, in constrast to previous findings, pronounced sea level rises of up to $25 \mathrm{~m}$ to generally correspond with Northern Hemisphere warmings as recorded in Greenland ice-core interstadial intervals whereas sea-level lowstands mostly occur during cold phases. Corroborated by CLIMBER-2 model results, the close connection of millennial-scale sealevel changes to Northern Hemisphere temperature variations indicates a primary climatic control on the mass balance of the major Northern Hemisphere ice sheets and does not require a considerable Antarctic contribution.
\end{abstract}

(C) 2006 Elsevier Ltd. All rights reserved.

\section{Introduction}

The global sea-level record since the last glacial maximum, $\sim 21,000$ years (ka) before present (BP), is relatively well known as it is based on numerous well-dated coral reef terraces (Fairbanks, 1989; Bard et al., 1996). Further back in the glacial, the coral-based data set becomes more incomplete and the reliably dated sea-level points, though showing the general amplitude of sea-level changes, are insufficient to establish the exact pattern and timing of millennial-scale changes (Chappell, 2002; Cutler et al., 2003). Alternatively, sea-level information can be derived from oxygen isotope $\left(\delta^{18} \mathrm{O}\right)$ records of benthic foraminifera that appear to show a global signal as a similar style of variability has been observed in different ocean basins (Shackleton et al., 2000; Pahnke and Zahn, 2005). However, the benthic records may be substantially

\footnotetext{
*Corresponding author. Tel.: + 49331288 1399; fax: + 493312881302.

E-mail address: harz@gfz-potsdam.de (H.W. Arz).

${ }^{1}$ Contributed equally to the paper.
}

biased by local hydrographic changes (Skinner et al., 2003) limiting their use as a global sea-level proxy. Another independent sea-level reconstruction based on $\delta^{18} \mathrm{O}$ of planktic foraminifera from the Red Sea has been recently shown to generally parallel the benthic $\delta^{18} \mathrm{O}$-based reconstructions (Siddall et al., 2003). Age-control in this reconstruction is however very limited and the crucial parts of the record have been tuned to the Antarctic Byrd icecore record (Blunier and Brook, 2001) and the Northeast Atlantic benthic $\delta^{18} \mathrm{O}$ record (Shackleton et al., 2000).

The pattern, timing, and source of global sea-level changes associated with millennial-scale climate fluctuations during the last glacial is crucial for a comprehensive understanding of glacial climate and ocean variability (Knutti et al., 2004; Rohling et al., 2004). The timing and shape of the published millennial-scale sea-level records have strong similarities to the rather symmetric and gradual Southern Hemisphere (SH) temperature variations as known from Antarctic ice-cores (Shackleton et al., 2000; Siddall et al., 2003; Rohling et al., 2004) and are thus markedly different from the abrupt and more asymmetric 
changes recorded in Greenland ice-cores (Grootes and Stuiver, 1997). This SH style of global sea-level variability with sea-level high-stands during Antarctic warming events (Blunier and Brook, 2001) and thus Northern Hemisphere (NH) cold phases (stadials), has been attributed to a decline of continental ice volume in the $\mathrm{NH}$ related to reduced snow accumulation (Shackleton et al., 2000) and/ or to meltwater pulses during Antarctic warming events (Rohling et al., 2004). It has been further suggested that during the most pronounced Greenland stadials, massive discharges of icebergs, so-called Heinrich events (HE), may have additionally contributed to the inferred sea-level highstands (Hemming, 2004). Compared to the previous sea-level reconstruction from the central Red Sea (Siddall et al., 2003), our new northern Red Sea record provides substantially improved age control (based on extensive ${ }^{14} \mathrm{C}$ dating and paleomagnetics) and suggests that major millennial-scale sea-level highstands during the last glacial occurred in phase with $\mathrm{NH}$ interstadials.

\section{Material and methods}

Core GeoB 5844-2 (core length $1235 \mathrm{~cm}$ ) was recovered during the German R/V Meteor cruise 44/3 from the northern end of the Red Sea $\left(27^{\circ} 42.8^{\prime} \mathrm{N}, 34^{\circ} 40.9^{\prime} \mathrm{E}\right)$, off the tip of the Sinai peninsula (Pätzold and cruise participants, 1999) at a water depth of $963 \mathrm{~m}$ (Fig. 1). Holocene and deglacial paleodata of the core have been previously published (Arz et al., 2003a, b). In the present paper, we focus on the glacial interval between $\sim 10$ and $\sim 80 \mathrm{ka} \mathrm{BP}$ (corresponding to $70-620 \mathrm{~cm}$ core depth). The glacial sediments are light gray to olive gray and mainly consist of nannofossil clayey muds to nannofossil oozes. The carbonate content is $40-60 \mathrm{wt} \%$, the total organic carbon averages $0.5 \mathrm{wt} \%$, and the terrigenous content is accordingly relative high.

\subsection{Age model}

The age model for core GeoB 5844-2 is based on $18{ }^{14} \mathrm{C}$ dates and additional paleomagnetic dating points (Figs. 2

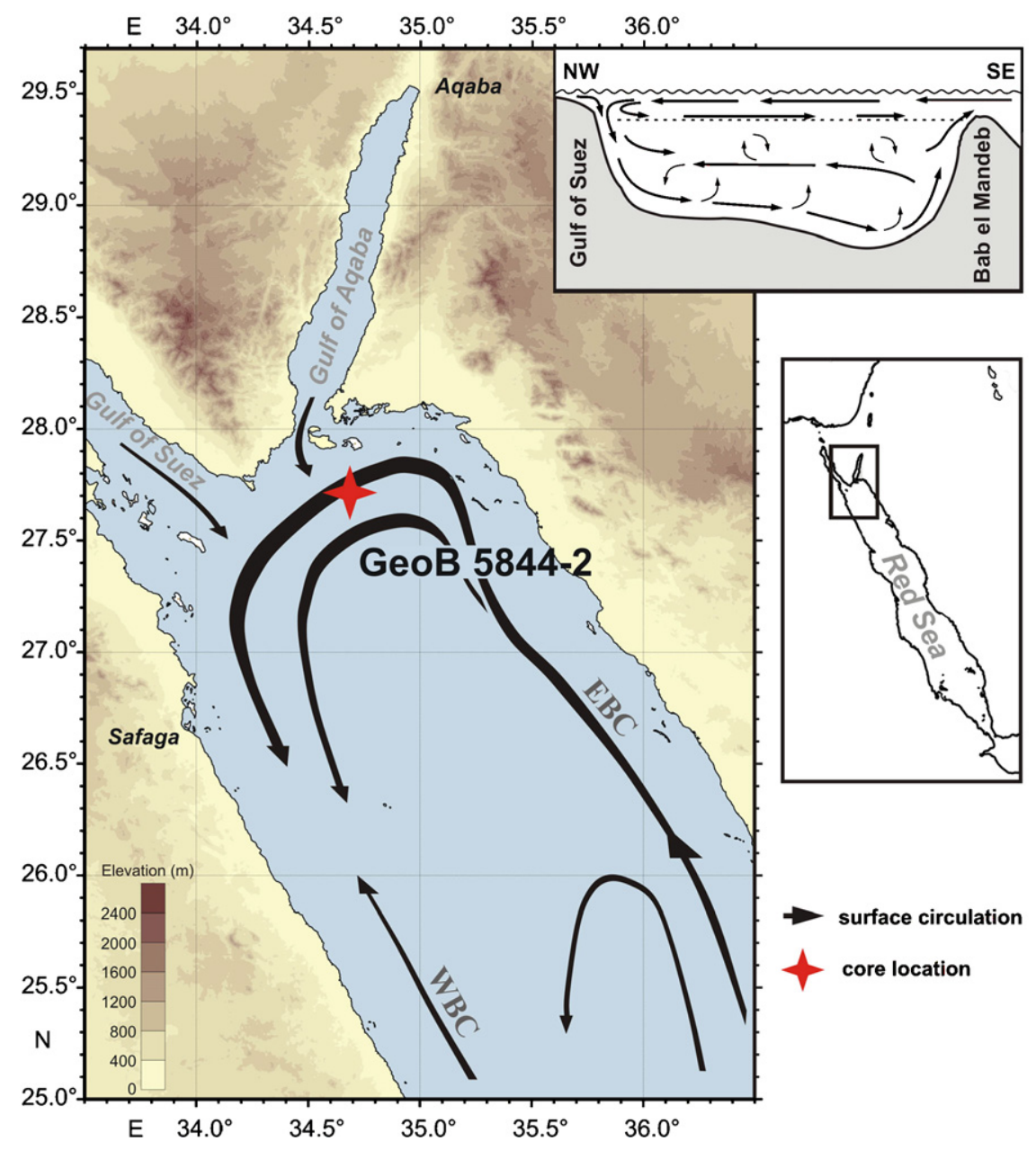

Fig. 1. Map of the northern Red Sea showing the surface circulation (Eshel and Naik, 1997), the areas of intermediate and deep water formation, and the location of core GeoB 5844-2 that was recovered during the German R/V Meteor cruise 44/3 from the northern end of the Red Sea, off the tip of the Sinai peninsula (Pätzold and cruise participants, 1999). The upper right panel shows a schematic representation of the anti-estuarine circulation in the Red Sea. Depending on the different authors, estimates of the average residence time of the deep water vary between 200 and 300 years and 30 and 70 years (Woelk and Quadfasel, 1996). 


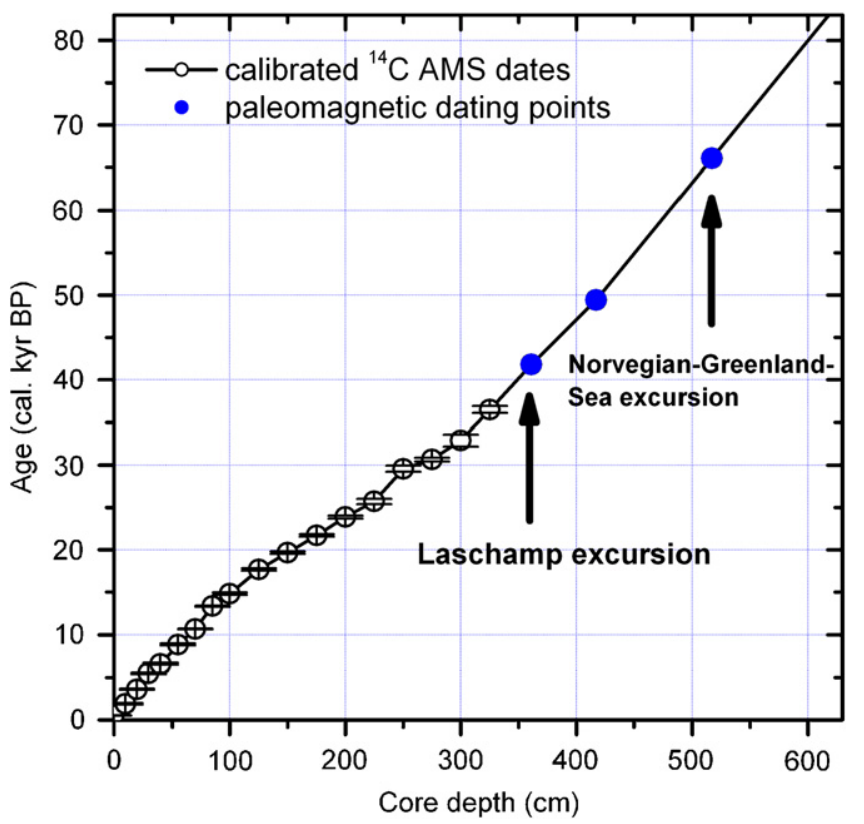

Fig. 2. Age model of core GeoB 5844-2. Open circles (with error margins) show ${ }^{14} \mathrm{C}$-AMS datings and filled blue circles the correlation of our magnetic paleointensity record to the North Atlantic paleointensity stack (NAPIS) (Laj et al., 2000; Stoner et al., 2002) (Fig. 3 and Table 1). Age control points are linearly interpolated.

and 3; Table 1) with linear interpolation between the dates. The ${ }^{14} \mathrm{C}$-AMS based age model is used until $\sim 37 \mathrm{ka}$ (Table 1). Beyond this, we use paleomagnetic evidence.

\subsubsection{Radiocarbon dating}

Carbonate samples of mainly monospecific composition (Globigerinoides sacculifer, Orbulina universa, Creseis acicula, Creseis virgula, or Limacina inflata) were dated with a ${ }^{14} \mathrm{C}$ Accelerated Mass Spectrometer (AMS). Carbonate hydrolysis and $\mathrm{CO}_{2}$ reduction of the samples were performed at the University of Bremen, Germany, and the ${ }^{14} \mathrm{C}$ AMS measurements were done at the AMS facility of the Leibniz Labor in Kiel, Germany. According to the Marine Reservoir Correction Database compiled by P. Reimer (http://www.depts.washington.edu/qil/marine/), a regional deviation $(\Delta R)$ of $\sim 170$ years from the average global reservoir effect ( $\sim 400$ years) was considered.

All ${ }^{14} \mathrm{C}$ ages were calibrated with the CalPal software (http://www.calpal.de; Jöris and Weninger, 1998) using the new CalPal_2005_SFCP calibration curve (SFCP stands for the initials of the contributing authors in Shackleton et al., 2004) that considers the most important recent calibrations for different time-intervals (Beyond the treering calibrated Holocene interval identical to the $I N$ TCAL04; (Reimer et al., 2004), a cubic spline with variable shape was built through U/Th-coral data (Fairbanks et al., 2005) and several other radiocarbon data sets (Hughen et al., 2000, 2004; Voelker et al., 2000; Bard et al., 2004) that have been transferred to the new SFCP timescale (Shackleton et al., 2004). This timescale represents a

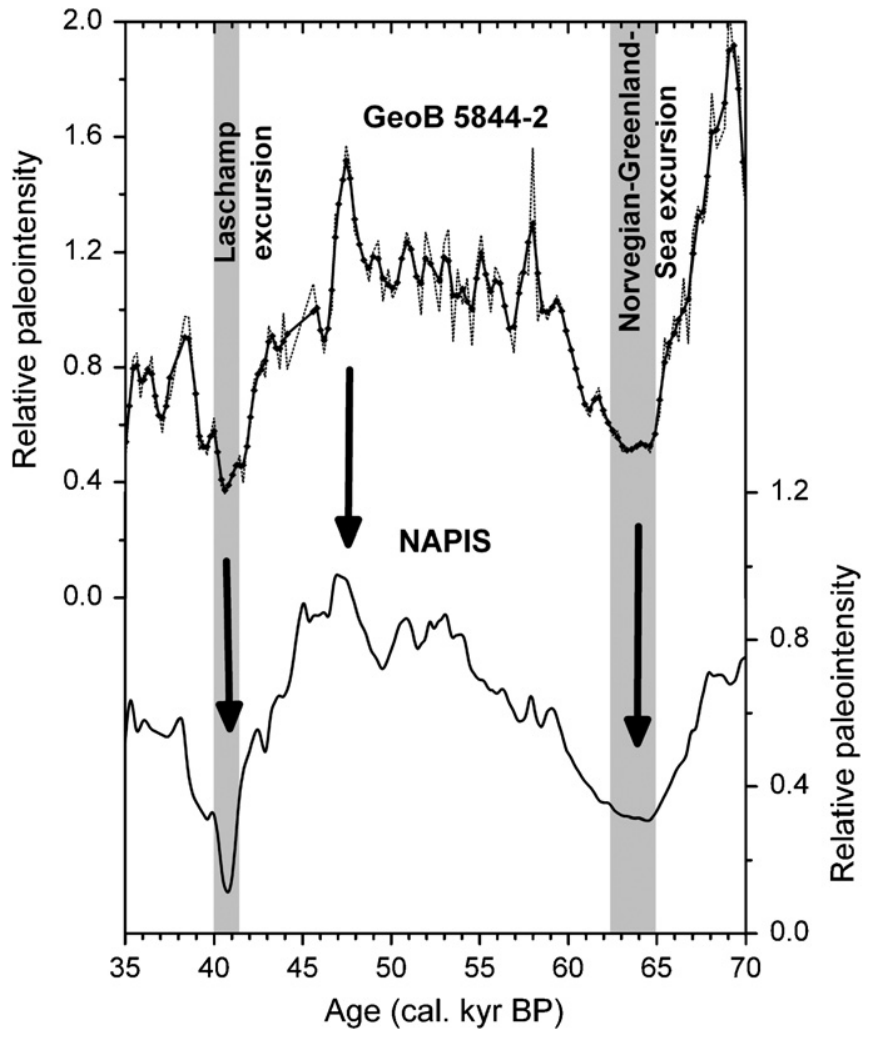

Fig. 3. Correlation of the GeoB 5844-2 magnetic paleointensity record to the North Atlantic paleointensity stack (NAPIS) (Laj et al., 2000; Stoner et al., 2002). Tie points used for the best fit are marked by vertical arrows and include the Laschamp event at $\sim 41 \mathrm{ka}(\sim 42 \mathrm{ka}$ on the SFCP timescale), one paleointensity maxima at $\sim 47 \mathrm{ka}$ BP ( $49 \mathrm{ka}$ on the SFCP timescale), and a paleointensity minimum at $\sim 64.5 \mathrm{ka} \mathrm{BP}$ ( $66 \mathrm{ka}$ on the SFCP timescale) that has been previously found in several North Atlantic records and described as Norwegian-Greenland Sea event (Nowaczyk and Frederichs, 1999). Dotted line shows original data of the GeoB 5844-2 magnetic paleointensity record and the bold line with symbols the 3-point weighted average.

revised version of the GRIP ice-core timescale determined by applying two age-constraints to the Greenland ice-age scale (one at $29 \mathrm{ka}$ for the base of GIS 3 based on the calibration of radiocarbon dates in North Atlantic sediment core MD95-2042 using the Fairbanks et al. (2005) calibration data set; and one at $59 \mathrm{ka}$ for the base of GIS 17, based on radiometrically dated speleothem records) additionally validating it with $\mathrm{U}-\mathrm{Th}$ dates from stalagmites and calibrated radiocarbon ages from core MD95-2042. Accordingly, for the relevant section in marine isotope stage 3, the age calibration results achieved with CalPal_SFCP_2005 are very similar to the results obtained by using the new coral U/Th calibration curve of Fairbanks et al. (2005) stand-alone with the software supplied at the LDEO web-site (http://www.radiocarbon. ldeo.columbia.edu/research/radiocarbon.htm) (Table 1).

\subsubsection{Paleomagnetic stratigraphy}

For paleomagnetic investigations, the sediment core has been sampled using cubic $(20 \times 20 \times 15 \mathrm{~mm})$ plastic boxes 
Table 1

Age model of GeoB 5844-2, northern Red Sea, including ${ }^{14} \mathrm{C}$ AMS datings and paleomagnetic tie-points to the NAPIS stack (Stoner et al., 2002)

\begin{tabular}{|c|c|c|c|c|c|c|c|c|}
\hline \multirow[t]{2}{*}{ Lab.-ID } & \multirow[t]{2}{*}{ Core depth $(\mathrm{cm})$} & \multirow[t]{2}{*}{ Foraminifera species } & \multicolumn{2}{|c|}{${ }^{14} \mathrm{C}$ AMS (yr BP) } & \multicolumn{4}{|c|}{ Calibrated age (cal yr BP) } \\
\hline & & & Age & \pm Err & CalPal & \pm Err & Fairbanks & \pm Err \\
\hline KIA11088 & 0 & G. sacculifer & 1015 & \pm 35 & 510 & \pm 30 & 505 & \pm 19 \\
\hline KIA11090 & 10 & O. universa & 2490 & \pm 80 & 1870 & \pm 100 & 1866 & \pm 90 \\
\hline KIA11091 & 20 & G. sacculifer & 3920 & \pm 45 & 3590 & \pm 70 & 3589 & \pm 60 \\
\hline KIA11092 & 30 & G. sacculifer & 5325 & \pm 50 & 5470 & \pm 90 & 5506 & \pm 76 \\
\hline KIA11094 & 40 & G. sacculifer & 6320 & \pm 100 & 6560 & \pm 110 & 6546 & \pm 118 \\
\hline KIA11275 & 55 & G. sacculifer & 8525 & \pm 55 & 8820 & \pm 120 & 8814 & \pm 131 \\
\hline KIA11276 & 70 & G. sacculifer & 9990 & \pm 50 & 10650 & \pm 60 & 10653 & \pm 67 \\
\hline \multirow[t]{2}{*}{ KIA11277 } & 85 & Creseis spp. and & & & & & & \\
\hline & & Limacina spp. & 12030 & \pm 55 & 13360 & \pm 80 & 13369 & \pm 110 \\
\hline KIA11279 & 100 & Creseis acicula & 13120 & \pm 60 & 14840 & \pm 150 & 14745 & \pm 130 \\
\hline KIA11280 & 125 & Creseis acicula & 14960 & \pm 120 & 17680 & \pm 160 & 17438 & \pm 215 \\
\hline KIA11281 & 150 & Creseis acicula & 17030 & \pm 90 & 19670 & \pm 140 & 19581 & \pm 116 \\
\hline KIA11283 & 175 & Creseis acicula & 18580 & \pm 100 & 21700 & \pm 130 & 21478 & \pm 144 \\
\hline \multirow[t]{2}{*}{ KIA11284 } & 200 & Creseis spp. and & & & & & & \\
\hline & & Limacina spp. & 20540 & \pm 120 & 23870 & \pm 170 & 23927 & \pm 151 \\
\hline KIA11285 & 225 & Creseis virgula & 22090 & \pm 160 & 25720 & \pm 310 & 25921 & \pm 239 \\
\hline \multirow[t]{2}{*}{ KIA11287 } & 250 & Creseis spp. and & & & & & & \\
\hline & & Limacina spp. & 25110 & \pm 210 & 29580 & \pm 370 & 29179 & \pm 325 \\
\hline \multirow[t]{2}{*}{ KIA11288 } & 275 & G. ruber and & & & & & & \\
\hline & & Creseis spp. & 26360 & \pm 240 & 30660 & \pm 220 & 30952 & \pm 202 \\
\hline \multirow[t]{2}{*}{ KIA11289 } & 300 & G. ruber and & & & & & & \\
\hline & & Creseis spp. & 28890 & \pm 290 & 32890 & \pm 710 & 33005 & \pm 313 \\
\hline KIA11291 & 325 & G. ruber & 32060 & \pm 400 & 36500 & \pm 400 & 36468 & \pm 407 \\
\hline \multicolumn{2}{|c|}{ Core depth $(\mathrm{cm})$} & \multicolumn{3}{|c|}{ Paleomagnetic excursions } & & & \multicolumn{2}{|c|}{ Age (cal yr BP) } \\
\hline \multicolumn{2}{|l|}{361} & \multicolumn{3}{|c|}{ Laschamp event } & & & \multicolumn{2}{|c|}{41800} \\
\hline \multicolumn{2}{|l|}{417} & \multicolumn{3}{|c|}{ - } & & & \multicolumn{2}{|c|}{49400} \\
\hline \multicolumn{2}{|l|}{517} & \multicolumn{3}{|c|}{ Norwegian-Greenland-Sea event } & & & \multicolumn{2}{|c|}{66100} \\
\hline
\end{tabular}

${ }^{14} \mathrm{C}$ dates are calibrated with the CalPal software using the CalPal_2005_SFCP calibration curve. For comparison, we also show the ages calibrated with the online software supplied at the Lamont web-site using the new Fairbanks U/Th calibration curve (Fairbanks et al., 2005).

in two alternating parallel rows with the diagonal parallel to the core's axis. Thus, on average, the sample spacing is reduced to about $17 \mathrm{~mm}$ with a triangular weighting of the sediment's magnetization, instead of a rectangular weighting in a standard sampling procedure with the sample boxes' edges parallel to the core axis. The natural remnant magnetization (NRM) of the samples were measured and stepwise demagnetized with alternating fields of up to $100 \mathrm{mT}$ using a cryogenic long-core magnetometer with inline tri-axial alternating field demagnetizer (2G755SRM). The obtained results were analysed by principle component analysis, generally using the demagnetization steps from 15 to $80 \mathrm{mT}$. For estimating the concentration of magnetic carrier minerals the samples then were subjected to an alternating field of $100 \mathrm{mT}$ superimposed by a DC field of $50 \mu \mathrm{T}$ in order to imprint an ahysteretic remnant magnetization (ARM), which was then demagnetized in a similar way as the NRM. Normalized relative paleointensity estimations were calculated on basis of NRM and ARM intensities, both demagnetized with $30 \mathrm{mT}$. Core intervals affected by diagensis (organic-rich layers) were excluded before paleointesity calculations. Therefore, we show the record from about $35-70 \mathrm{ka}$, with two small gaps at around 39 and $47 \mathrm{ka}$. Further details on the method are described in Nowaczyk et al. (2001).

We correlated our GeoB 5844-2 magnetic paleointensity record to the North Atlantic paleointensity stack (NAPIS) (Laj et al., 2000; Stoner et al., 2002) (Fig. 3). We used a minimum number of tie points that include the intensity low associated with the Laschamp event at $\sim 42 \mathrm{ka}$ BP as the most prominent feature in late Pleistocene paleointensity fluctuations of the geomagnetic field (the Laschamp paleomagnetic excursion ties directly to the ${ }^{10} \mathrm{Be}$ and ${ }^{36} \mathrm{Cl}$ anomalies of the Greenland interstadial 10 (Muscheler et al., 2005)), an paleointensity peak at $\sim 49 \mathrm{ka} \mathrm{BP}$, and a paleointensity minimum at $\sim 65 \mathrm{ka} B P$ that has been previously found in several North Atlantic records and described as Norwegian-Greenland Sea excursion (Nowaczyk and Frederichs, 1999). Taking the established correlation of the NAPIS stack to the Greenland ice-core records as shown in Stoner et al. (2002), we transferred the ages to the SFCP age scale as well (Shackleton et al., 2004). We are, however, aware of increasingly higher errors in the absolute ages for this time interval. Another independent proof for the reliability of our age model is the clear NH pattern in our alkenone sea surface temperature (SST) 
record with coolings during major Greenland stadials and HEs (see Section 3.1). This pattern is consistent with our previous results on the deglaciation (Arz et al., 2003b) and other SST records form the North Atlantic and the Mediterranean Sea (e.g., Cacho et al., 1999; Bard, 2002).

\subsection{Oxygen isotopes}

Stable oxygen isotope measurements were performed on the planktonic foraminifera Globigerinoides ruber (white), the nonmigratory pteropods Creseis acicula and Creseis virgula, and the benthic foraminifera Cibicides mabahethi and Bulimina marginata. To avoid size-dependent effects on the $\delta^{18} \mathrm{O}$ values and to reduce potential intrasample noise, 50 specimens of $350-400 \mu \mathrm{m}$ diameter (measured along the longest axis) of $G$. ruber (white) and about 30 specimens of $C$. acicula and $C$. virgula were hand-picked and homogenized. About 20 and 10 specimens of $C$. mabahethi and $B$. marginata, respectively, were used for each measurement. Samples were analyzed using a Finnigan MAT 251 mass spectrometer coupled to an automated carbonate preparation system (Kiel device) at the University of Bremen. Analytical internal longtime precision for $\delta^{18} \mathrm{O}$ as defined by the reproducibility of carbonate standards was better than $\pm 0.07 \%$. We adjusted $\delta^{18} \mathrm{O}$ values of $C$. acicula $/ C$. virgula to $G$. ruber by subtracting $1.9 \%$ determined from paired masurements. Paired measurements of the two-benthic foraminifera showed that there is virtually no offset in $\delta^{18} \mathrm{O}$ between these species. The $\delta^{18} \mathrm{O}$ measurements on the different species are linearly related with a slope 1:1 (slope for the benthic species is 1.01 and for the planktonic species 1.05).

\subsection{Alkenone paleothermometry}

Alkenones were extracted from 5-10g portions of the freeze-dried and homogenized sediment following a procedure described in detail elsewhere (Müller et al., 1998; Arz et al., 2003b). The measurements obtained by split (1:20) (used in this study) and on-column injection did not show any systematic difference. Surface sediments $(0-1 \mathrm{~cm})$ collected with a multi-corer in the study area show $U_{37}^{K^{\prime}}$ values between 0.938 and 0.945 , or $26.5 \pm 0.1{ }^{\circ} \mathrm{C}$ in terms of temperature, ranging midway between the mean annual $\left(25.3^{\circ} \mathrm{C}\right)$ and summer $\left(27.7^{\circ} \mathrm{C}\right)$ temperatures for this region.

\subsection{Sea-level reconstruction}

$\delta^{18} \mathrm{O}_{\mathrm{w}}$ was calculated from the benthic $\delta^{18} \mathrm{O}$ calcite $\left(\delta^{18} \mathrm{O}_{\mathrm{c}}\right)$ record considering two temperature end-member scenarios; the first scenario taking the full range of alkenone SSTs changes into account (calculated as the temperature departure from the present deep water temperature) and the second scenario assuming a constant deep water temperature. Because of the exceptionally warm bottom-water temperatures in the Red Sea, published paleotemperature equations for benthic foraminifera (Bemis et al., 1998) do not cover the temperature range relevant for our study. Therefore we used the linear paleotemperature equation of Bemis et al. (Bemis et al., 1998), $T=16.5-4.8\left(\delta^{18} \mathrm{O}_{c}-\delta^{18} \mathrm{O}_{w}\right)$, which has been experimentally established for the planktonic foraminifera Orbulina universa under low light conditions and is valid also for the "cold temperature" range (Bemis et al., 1998) as for example is present in the Red Sea deep water. Accordingly, core-top measurements (Arz et al., 2003b) are in good agreement with theoretically derived $\delta^{18} \mathrm{O}_{\mathrm{c}}$ values.

To match the average resolution of the alkenone SST record, we interpolated the $\delta^{18} \mathrm{O}_{\mathrm{c}}$ record to a resolution of 200 years and slightly smoothed the isotope record in order to reduce inter-sample noise by applying a 5-point moving average. We established a separate sea-level- $\delta^{18} \mathrm{O}_{\mathrm{w}}$ relationship for each $\delta^{18} \mathrm{O}_{\mathrm{w}}$ record (from the two temperature scenarios) by using coral-based sea-level data (i.e., Fairbanks, 1989; Chappell, 2002; Cutler et al., 2003; Thompson and Goldstein, 2005) as constraints (Fig. 4).

\subsection{Ice sheet modelling}

Simulations of the difference in annual mean precipitation, rate of surface ablation, and total surface mass

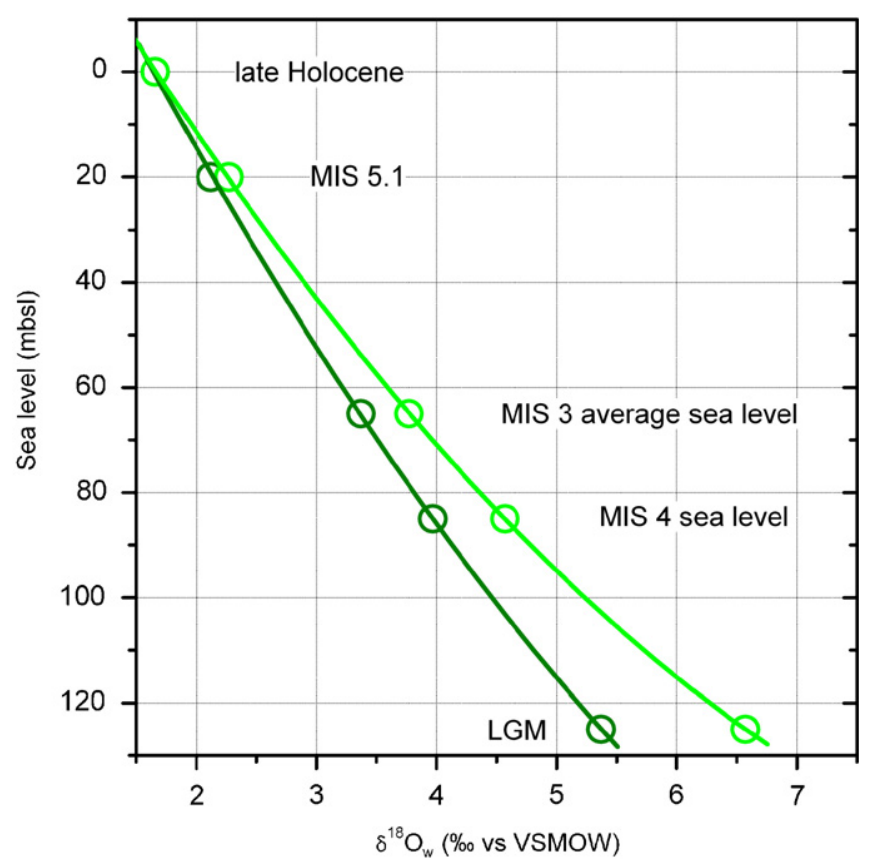

Fig. 4. Sea-level- $\delta^{18} \mathrm{O}_{\mathrm{w}}$ relationships for the northern Red Sea used in this study. The dark green line shows the relationship established for the temperature-corrected benthic isotopes and the light green line the relationship for the benthic isotopes without temperature correction. Circles denote the coral-based sea-level data used as constraints for the sea-level- $\delta{ }^{18} \mathrm{O}_{\mathrm{w}}$ relationships. Sea-level data from fossil corals for MIS 5.1 ( $\sim 20 \mathrm{~m}$ b.s.l.; Thompson and Goldstein, 2005), the average MIS 3 highstands ( $\sim 65 \mathrm{~m}$ b.s.l.; Chappell, 2002; Cutler et al., 2003), the MIS 4 low stand ( $\sim 85 \mathrm{~m}$ b.s.l.; Chappell, 2002; Cutler et al., 2003), and the LGM low stand ( $\sim 125 \mathrm{~m}$ b.s.l.; Fairbanks, 1989; Chappell, 2002; Cutler et al., 2003) were combined with the corresponding average $\delta^{18} \mathrm{O}_{\mathrm{w}}$ data, and subsequently used to establish the new sea-level- $\delta^{18} \mathrm{O}_{\mathrm{w}}$ relationships. 
balance of the glacial ice sheets between interstadial and stadial were performed with the CLIMBER-2 model (Petoukhov et al., 2000) for the LGM boundary conditions. Ice sheets were prescribed following the ICE-5G reconstruction (Peltier, 2004) and $\mathrm{CO}_{2}$ concentration was set to $190 \mathrm{ppm}$. Interstadial conditions correspond to the "warm" mode, and stadial to the "cold" mode of the Atlantic thermohaline circulation (Ganopolski and Rahmstorf, 2001). Surface mass balance of the ice sheets was computed using a high-resolution mass balance model (Calov et al., 2002).

\section{Results and discussion}

\subsection{The northern Red Sea sea-level record}

The unique sensitivity of the Red Sea to global sea-level changes is a consequence of the narrow and shallow $(137 \mathrm{~m})$ connection to the Indian Ocean (Strait of Bab el Mandeb) (Werner and Lange, 1975; Fig. 1). Sea-level lowering substantially reduces the exchange with the Indian Ocean through the strait (only $\sim 6 \mathrm{~km}$ wide at the LGM). Due to the strong regional aridity, high evaporation rates result in increased salinity and $\delta^{18} \mathrm{O}$ of sea water $\left(\delta^{18} \mathrm{O}_{\mathrm{w}}\right)$ with lower global sea-level (Siddall et al., 2003). Siddall et al. $(2003,2004)$ recently combined a hydraulic model for the water exchange across the Strait of Bab el Mandeb with a basin model of the Red Sea in order to quantify the effect of sea-level changes on $\delta^{18} \mathrm{O}_{\mathrm{w}}$. These data were then used to translate $\delta^{18} \mathrm{O}$ calcite $\left(\delta^{18} \mathrm{O}_{\mathrm{c}}\right)$ records based on planktic foraminifera from sediment cores in the central Red Sea to a continuous sea-level record (Fig. 5F). The sensitivity of the model-based sealevel reconstruction related to processes other than the sill constriction at Bab el Mandeb (e.g. to large changes in net evaporation and temperature) gives a combined model uncertainty of $\pm 12 \mathrm{~m}$ on the sea-level estimates, a uncertainty that can roughly be assessed for our sea-level estimates as well.

In our study, we focus on the benthic $\delta^{18} \mathrm{O}_{\mathrm{c}}$ record. Though the planktic and benthic records are strikingly similar (Fig. 5C), we regard the benthic record as more reliable because the planktic data set is composed of three different species and may be biased by local changes in evaporation and precipitation (Arz et al., 2003a). For the calculation of our sea-level record, we consider two endmembers: In the first case, we assume that the full amplitude of surface water temperature changes penetrated to the deep basin and use the alkenone SST record (Fig. 5B) to calculate $\delta^{18} \mathrm{O}_{\mathrm{w}}$. This maximum-approach tends to overestimate the temperature effect because temperature amplitudes may have been attenuated to a certain degree and the overall benthic $\delta^{18} \mathrm{O}_{\mathrm{c}}$-amplitude is somewhat lower than the planktic one. As a second end member, we therefore assumed that deep-water temperatures did not change significantly through time. For both assumptions, we then established new sea-level- $\delta^{18} \mathrm{O}_{\mathrm{w}}$

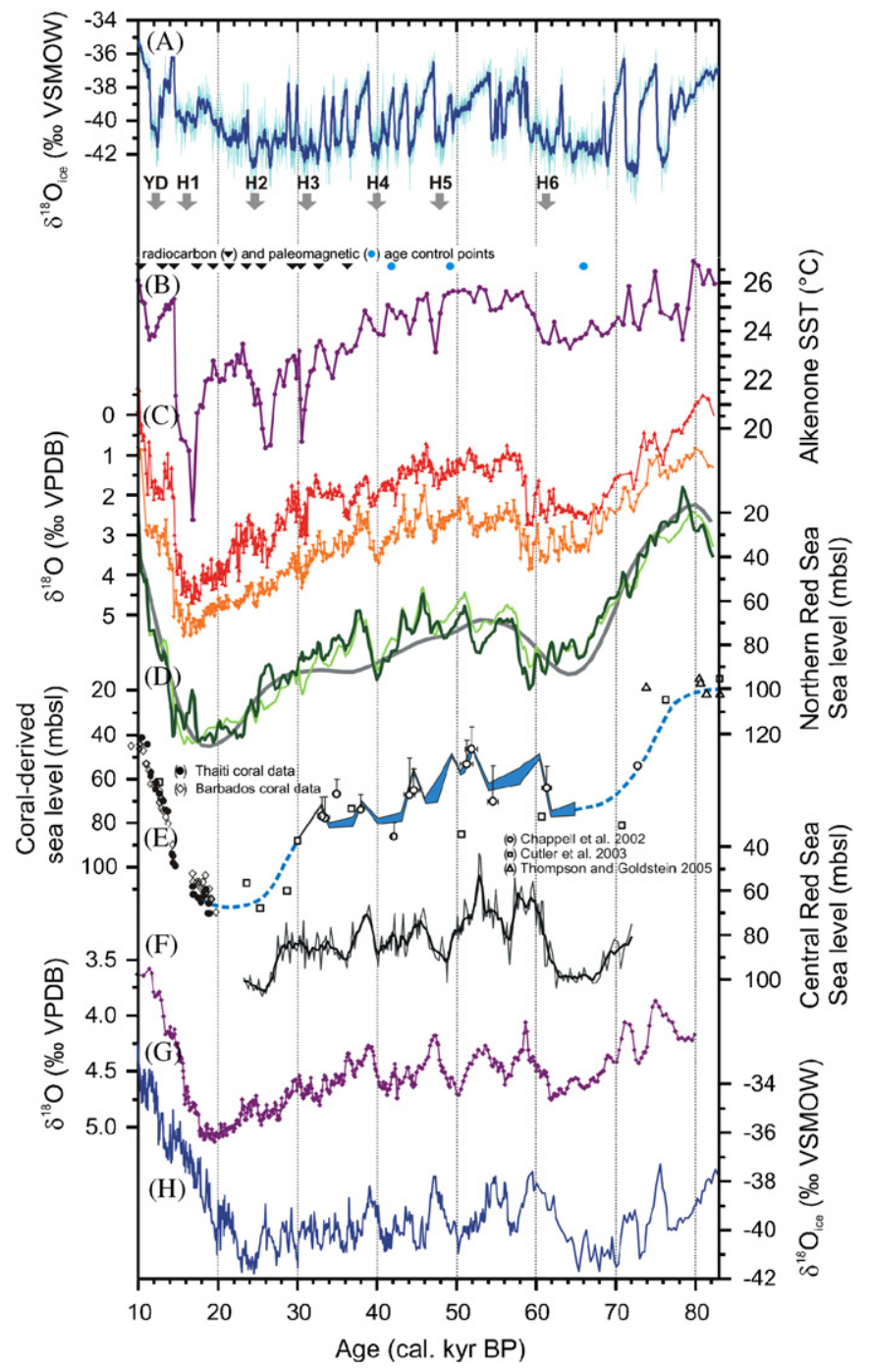

Fig. 5. Sea-level reconstructions from the northern Red Sea compared to previous sea-level estimates, the North Atlantic benthic isotope record, and temperature records from Greenland and Antarctica. (A) $\delta^{18} \mathrm{O}$ record of the GRIP ice-core (Greenland) on the SFCP timescale (Shackleton et al., 2004). (B) Alkenone SST record from core GeoB 5844-2 (this study). (C) Planktic (red) and benthic (orange) $\delta^{18} \mathrm{O}$ records from core GeoB 5844-2 (this study). The benthic record is used for the sea-level reconstruction. (D) Sea-level reconstruction from the northern Red Sea (this study) based on the benthic $\delta^{18} \mathrm{O}$ record considering two temperature corrections: in dark green the alkenone SSTs as a maximum assumption for deep water temperature changes (benthic $T_{\max }$ ), and in light green constant temperatures as a minimum approach (benthic $T_{\min }$ ); Gray line shows the sea-level estimate based on the SPECMAP $\delta^{18} \mathrm{O}$ stack (Imbrie et al., 1984) modified after Cutler et al. (2003). (E) Coral-based sea-level estimates from Barbados corals (open diamonds and open triangles) (Fairbanks, 1989; Cutler et al., 2003; Thompson and Goldstein, 2005), Thaiti corals (filled circles) (Bard et al., 1996), and the Huon Peninsula (open triangles and squares) (Chappell, 2002; Cutler et al., 2003). (F) Sea-level reconstruction from the central Red Sea (Siddall et al., 2003) (transferred to the SFCP2004 timescale after Shackleton et al., 2004). (G) Benthic $\delta^{18} \mathrm{O}$ record from core MD 95-2042 located at the Iberian margin (Shackleton et al., 2000) on the SFCP2004 timescale (Shackleton et al., 2004). (H) $\delta^{18} \mathrm{O}$ of the Byrd ice-core (Antarctica) (Blunier and Brook, 2001) transferred to the SFCP2004 timescale. All records are plotted on the SFCP timescale except for the coral data sets and the SPECMAP curve for which the original stratigraphy has not been changed. 


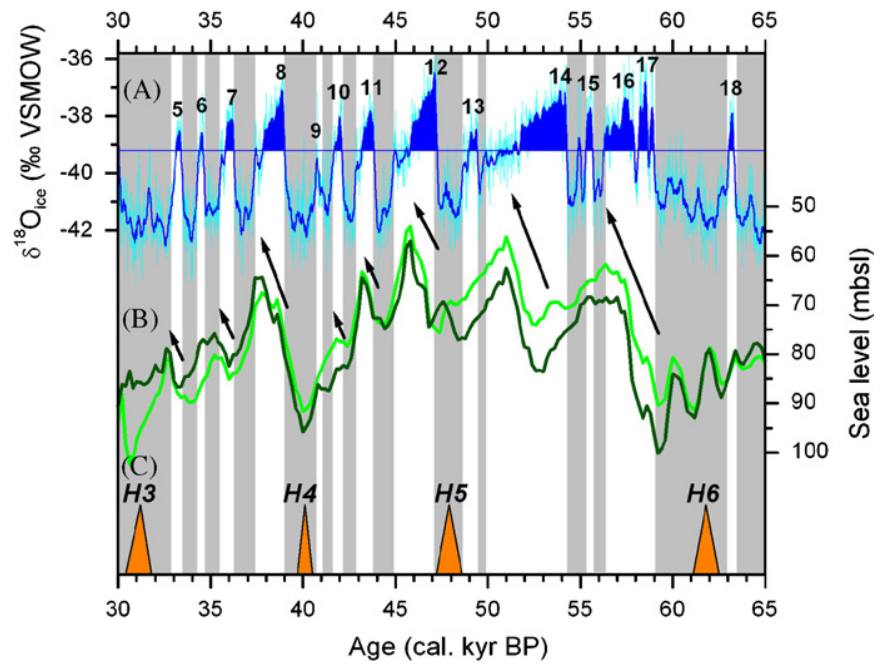

Fig. 6. Detail of sea-level changes during MIS 3 compared to Greenland temperature changes and the occurrence of Heinrich events in the North Atlantic. Gray bars mark major Northern Hemisphere cold phases (stadials). (A) $\delta^{18} \mathrm{O}$ record of the GRIP ice-core (Greenland) on the SFCP timescale (Shackleton et al., 2004). Interstadials are numbered. (B) Sealevel reconstruction from the northern Red Sea (this study) based on the benthic $\delta^{18} \mathrm{O}$ record (temperature and non-temperature corrected, see Fig. $3)$. Arrows denote major sea-level rises during Greenland interstadials. (C) Heinrich events $(\mathrm{H}) 3$ to 6 (ages from Hemming (2004) transferred to the SFCP2004 timescale (Shackleton et al., 2004)).

relationships (Fig. 4). Given the fact that the Red Sea deep water is a relatively warm water mass that probably closely communicated with the upper water column during the glacial period (e.g., von Gyldenfeldt, 1999) we regard the first assumption as the more likely one.

The resulting sea-level curve from the northern Red Sea (Fig. 5D) confirms the general pattern of sea-level variability during the last $80 \mathrm{ka}$ (Imbrie et al., 1984; Siddall et al., 2003; Shackleton et al., 2004; Thompson and Goldstein, 2005) as the orbital-scale sea-level changes fit well to the coral (Fairbanks, 1989; Bard et al., 1996; Chappell, 2002; Cutler et al., 2003; Thompson and Goldstein, 2005) and isotope-based reconstructions (Imbrie et al., 1984) (Fig. 5). On millennial timescales, however, our new record suggests that major MIS 3 sea-level rises occurred during $\mathrm{NH}$ interstadials and thus contrasts previous conclusions (Shackleton et al., 2000; Siddall et al., 2003; Rohling et al., 2004). Especially the longer and more pronounced interstadials $8,12,14$, and 16/17 are associated with a sea-level increase of 15-25 m (Fig. 6).

\subsection{The sea-level response on $\mathrm{NH}$ ice sheet behaviour in the course of DO climate variability}

It is generally accepted that variations of ice volume on orbital timescales are tightly coupled to the $\mathrm{NH}$ climate, with growth of ice sheets during cold periods, and shrinking during warm periods. Ice core and marine records suggest that major stadial-interstadial transitions are connected with abrupt temperature increases in the order of $9-16^{\circ} \mathrm{C}$ over Greenland (Johnsen et al., 2001) and
4-5 ${ }^{\circ} \mathrm{C}$ in the North Atlantic surface waters (Bard, 2002). Thus, the magnitude of millennial-scale temperature changes is comparable with that induced by orbital forcing, and it has been so far unexplained why these abrupt climate changes did not exert a strong impact on the mass balance of ice sheets. Indeed, results of experiments with climate-ice sheet models show a considerable negative change in mass balance of the $\mathrm{NH}$ ice sheets with the transition from stadial to interstadial conditions and a substantial interstadial freshwater output (Zweck and Huybrechts, 2005) ranging from several meters to several tens of meters of sea-level rise (e.g., Charbit et al., 2002; Schmittner et al. 2002). An experiment with the CLIMBER-2 model (Fig. 7) gives an intermediate result $(\sim 8 \mathrm{~m} / \mathrm{ka}$ sea-level rise). This experiment is fully consistent with our record and shows that the negative mass balance during interstadials is caused by enhanced ablation at the southern margins of the Fennoscandian and, even more pronounced, the Laurentide ice sheet (Fig. 7C). At the same time, precipitation doubles over the Fennoscandian ice sheet, resulting in a partly compensation of the increased melting. Already decreasing sea-level at the end of interstadials (Fig. 6) may suggest that increased snow accumulation under comparatively warm climate conditions triggers the resumption of ice sheet growth.
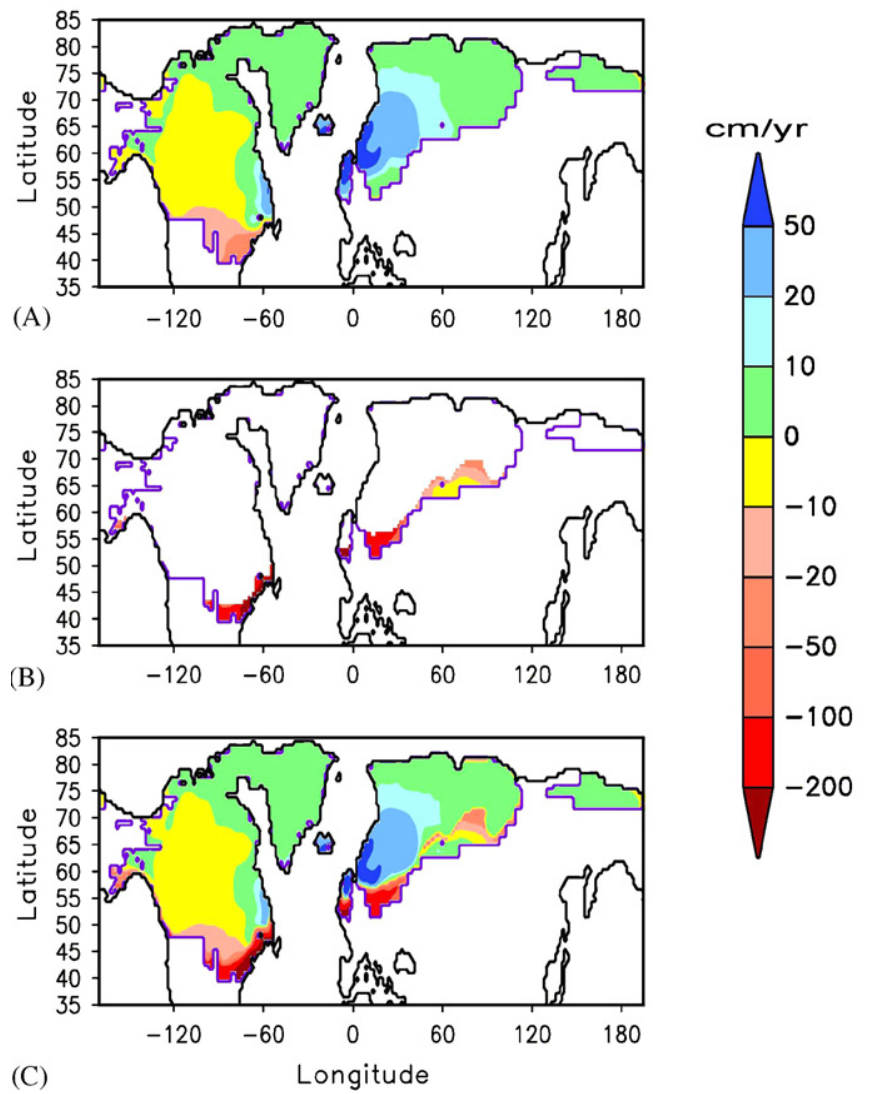

Fig. 7. Difference in annual mean (A) precipitation, (B) rate of surface ablation, and $(\mathrm{C})$ total surface mass balance of the ice sheets between interstadial (warm) and stadial (cold) glacial conditions simulated with the CLIMBER-2 model (Petoukhov et al., 2000). 
The close association of sea-level changes to $\mathrm{NH}$ interstadials during MIS 3 suggests that the melt-water contribution from Antarctica can only be minor. Based on the previous sea-level record from the central Red Sea (Siddall et al., 2003), an equal contribution from both icesheets during major Greenland stadials has been recently postulated (Rohling et al., 2004). This conclusion is primarily based on the fact that the modelled marine $\delta^{18} \mathrm{O}$ distribution for either $100 \% \mathrm{NH}$ or $\mathrm{SH}$ meltwater input is inconsistent with the observed values (based on planktonic foraminifera) and that the best match for a $30 \mathrm{~m}$ sea-level rise can be reached by applying a 50:50 scenario. Our data imply however that the input of isotopically very negative freshwater would have occurred during interstadials and could have been largely compensated due to a more vigorous interstadial Atlantic meridional overturning circulation (AMOC) (Rahmstorf, 2002). In addition, the amplitudes of millennial-scale sea-level changes in our record are generally lower than those previously reconstructed (Siddall et al., 2003). Thus, our results are more consistent with glaciological studies of the glacial Antarctic ice-sheet, which suggest a substantially more stable SH icesheet than the NH counterparts (Huybrechts, in press). Even if assuming rapid sea-level rises due to the partial collapse of the Antarctic ice sheet, the low snow accumulation rates over Antarctica (Huybrechts, in press) would exclude any significant sea-level lowering on such timescales.

\section{Conclusions}

The major implication of our new record that ice volume changes are primarily controlled by $\mathrm{NH}$ climate not only on orbital, but also on millennial timescales requires a rethinking of the role of climate-ice sheet interaction. Most modelling studies of millennial-scale climate and ocean circulation changes explained cold climate conditions over the North Atlantic during stadials, and, especially, during HE, by a reduction or even complete cessation of the AMOC caused by enhanced freshwater flux (Ganopolski and Rahmstorf, 2001; Knutti et al., 2004). Our new sealevel reconstruction suggests to the contrary that most melt-water is released during interstadials. Sea-level changes associated with HE are generally minor (Fig. 6) consistent with independent estimates that suggest a rather moderate sea-level rise of only a few meters during these events (Hemming, 2004; Roche et al., 2004). Thus our results require an explanation for the coexistence of large melt-water fluxes and a vigorous AMOC during interstadials. Part of this apparent contradiction may be explained by the fact that the impact of the same amount of freshwater on the AMOC strongly depends on the location of the freshwater anomaly (Manabe and Stouffer, 1997; Ganopolski and Rahmstorf, 2001). A relatively large freshwater input in the mid-latitudes due to melting of the southern flanks of the $\mathrm{NH}$ ice sheets during warm interstadial conditions (Fig. 7B) is much less efficient in affecting the ocean circulation compared to the relatively strong effect related to the melting of icebergs released from the northern part of the ice sheets directly into the area of deep water formation (e.g., Vidal et al., 1997). Since it is likely that these two different sources of freshwater are out of phase, i.e. the first operating during interstadials and the latter during HE, the evolution of the THC is not controlled by the bulk amount of freshwater flux into the North Atlantic, but rather by its spatial distribution. Our results therefore represent a clear challenge for the climate modeling and demonstrate that the contemporary view on millennial-scale climate variability is still oversimplistic and incomplete.

\section{Acknowledgments}

We thank Monika Segl and her team (University of Bremen) and Birgit Plessen (GFZ Potsdam) for carrying out the stable isotope measurements, as well as Peter Müller and Ralph Kreuz who performed the alkenone laboratory work in Bremen. We acknowledge Mark Siddall's contribution to our Red-Sea sea-level reconstruction. We also thank N. Shackleton for providing ice core data on the new SFCP timescale. We are grateful for the stimulating reviews of Luke Skinner and Nicolas Thouveny, which helped to improve the manuscript. We finally acknowledge the generous grant of permission for conducting research in the territorial waters of the Kingdom of Saudi Arabia. H.W.A. has been partly funded by the DFG, the RCOM, and the Gary Comer Science Foundation.

\section{References}

Arz, H.W., Lamy, F., Pätzold, J., Müller, P.J., Prins, M., 2003a. Mediterranean moisture source for an early-Holocene humid period in the northern Red Sea. Science 300, 118-122.

Arz, H.W., Pätzold, J., Müller, P.J., Moammar, M.O., 2003b. Influence of Northern Hemisphere climate and global sea level rise on the restricted Red Sea marine environment during termination I. Paleoceanography 18, doi:10.1029/2002PA000864.

Bard, E., 2002. Abrupt climate changes over millennial time scales: climate shock. Physics Today 55, 32-38.

Bard, E., Hamelin, B., Arnold, M., Montaggioni, L., Cabioch, G., Faure, G., Rougerie, F., 1996. Deglacial sea-level record from Tahiti corals and the timing of global meltwater discharge. Nature 382, 241-244.

Bard, E., Rostek, F., Menot-Combes, G., 2004. A better radiocarbon clock. Science 303, 178-179.

Bemis, B.E., Spero, H.J., Bijma, J., Lea, D.W., 1998. Reevaluation of the oxygen isotopic composition of planktonic foraminifera: experimental results and revised paleotemperature equations. Paleoceanography 13, $150-160$.

Blunier, T., Brook, E.J., 2001. Timing of millennial-scale climate change in Antarctica and Greenland during the last glacial period. Science 291, 109-112.

Cacho, I., Grimalt, J.O., Pelejero, C., Canals, M., Sierro, F.J., Flores, J.A., Shackleton, N., 1999. Dansgaard-Oeschger and Heinrich event imprints in Alboran Sea paleotemperatures. Paleoceanography 14, 698-705.

Calov, R., Ganopolski, A., Petoukhov, V., Claussen, M., Greve, R., 2002. Large-scale instabilities of the Laurentide ice sheet simulated in a fully coupled climate-system model. Geophysical Research Letters 29, 2216. 
Chappell, J., 2002. Sea level changes forced ice breakouts in the Last Glacial cycle: new results from coral terraces. Quaternary Science Reviews 21, 1229-1240.

Charbit, S., Ritz, C., Ramstein, G., 2002. Simulations of Northern Hemisphere ice-sheet retreat: sensitivity to physical mechanisms involved during the Last Deglaciation. Quaternary Science Reviews 21, 243-265.

Cutler, K.B., Edwards, R.L., Taylor, F.W., Cheng, H., Adkins, J., Gallup, C.D., Cutler, P.M., Burr, G.S., Bloom, A.L., 2003. Rapid sea-level fall and deep-ocean temperature change since the last interglacial period. Earth and Planetary Science Letters 206, 253-271.

Eshel, G., Naik, N.H., 1997. Climatological coastal jet collision, intermediate water formation, and the general circulation of the Red Sea. Journal of Physical Oceanography 27, 1233-1257.

Fairbanks, R.G., 1989. A 17,000-year glacio-eustatic sea level record: influence of glacial melting rates on the Younger Dryas event and deep-ocean circulation. Nature 342, 637-641.

Fairbanks, R.G., Mortlock, R.A., Chiu, T.-C., Cao, L., Kaplan, A., Guilderson, T.P., Fairbanks, T.W., Bloom, A.L., Grootes, P.M., Nadeau, M.-J., 2005. Radiocarbon calibration curve spanning 0 to 50,000 years BP based on paired $230 \mathrm{Th} / 234 \mathrm{U} / 238 \mathrm{U}$ and ${ }^{14} \mathrm{C}$ dates on pristine corals. Quaternary Science Reviews 24, 1781-1796.

Ganopolski, A., Rahmstorf, S., 2001. Rapid changes of glacial climate simulated in a coupled climate model. Nature 409, 153-158.

Grootes, P.M., Stuiver, M., 1997. Oxygen 18/16 variability in Greenland snow and ice with $10^{-3}$ to $10^{5}$-year time resolution. Journal of Geophysical Research 102, 26,455-26,470.

Hemming, S.R., 2004. Heinrich events: Massive late Pleistocene detritus layers of the North Atlantic and their global climate imprint. Reviews of Geophysics 42, RG1005.

Hughen, K.A., Southon, J.R., Lehman, S.J., Overpeck, J.T., 2000. Synchronous radiocarbon and climate shifts during the last deglaciation. Science 290, 1951-1954.

Hughen, K., Lehman, S., Southon, J., Overpeck, J., Marchal, O., Herring, C., Turnbull, J., 2004. ${ }^{14} \mathrm{C}$ activity and global carbon cycle changes over the past 50,000 years. Science 303, 202-207.

Huybrechts, P. Numerical modeling of polar ice sheets through time. In: Knight, P. (Ed.), Glacier Science and Environmental Change. Blackwell, Oxford, pp. 406-412.

Imbrie, J., Hays, J.D., Martinson, D.G., McIntyre, A., Mix, A.C., Morley, J.J., Pisias, N.G., Prell, W.L., Shackleton, N.J., 1984. The orbital theory of Pleistocene climate: support from a revised chronology of the marine $\delta^{18} \mathrm{O}$ record. In: Berger, A.L., Imbrie, J., Hays, J.D., Kukl, J., Saltzman, J. (Eds.), Milankovitch and Climate. Reidel Publishing Company, Hingham, pp. 269-305.

Johnsen, S.J., Dahl, J.D., Gundestrup, N., Steffensen, J.P., Clausen, H.B., Miller, H., Masson, D.V., Sveinbjornsdottir, A.E., White, J., 2001. Oxygen isotope and palaeotemperature records from six Greenland ice-core stations; Camp Century, Dye-3, GRIP, GISP2, Renland and NorthGRIP. Journal of Quaternary Science 16, 299-307.

Jöris, O., Weninger, B., 1998. Extension of the ${ }^{14} \mathrm{C}$ calibration curve to ca. 40,000 calBC by synchronizing Greenland ${ }^{18} \mathrm{O} /{ }^{16} \mathrm{O}$ ice core records and North Atlantic foraminifera profiles: a comparison with U/Th coral data. Radiocarbon 40, 495-504.

Knutti, R., Flückiger, J., Stocker, T.F., Timmermann, A., 2004. Strong hemispheric coupling of glacial climate through freshwater discharge and ocean circulation. Nature 430, 851-856.

Laj, C., Kissel, C., Mazaud, A., Channell, J.E.T., Beer, J., 2000. North Atlantic paleointensity stack since $75 \mathrm{ka}$ (NAPIS-75) and the duration of the Laschamp event. Philosophical Transactions of the Royal Society Series A 358, 1009-1025.

Manabe, S., Stouffer, R.J., 1997. Coupled ocean-atmosphere model response to freshwater input: comparison to Younger Dryas event. Paleoceanography $12,321-336$.

Müller, P.J., Kirst, G., Ruhland, G., von Storch, I., Rosell-Mele, A., 1998. Calibration of the alkenone paleotemperature index UK'37 based on core-tops from the eastern South Atlantic and the global ocean $\left(60^{\circ} \mathrm{N}-60^{\circ} \mathrm{S}\right)$. Geochimicaet Cosmochimica Acta 62, 1757-1772.
Muscheler, R., Beer, J., Kubik, P.W., Synal, H.-A., 2005. Geomagnetic field intensity during the last 60,000 years based on ${ }^{10} \mathrm{Be}$ and ${ }^{36} \mathrm{Cl}$ from the summit ice cores and ${ }^{14} \mathrm{C}$. Quaternary Science Reviews 24, 1849-1860.

Nowaczyk, N.R., Frederichs, T.W., 1999. Geomagnetic events and relative palaeointensity variations during the past $300 \mathrm{ka}$ as recorded in Kolbeinsey Ridge sediments, Iceland Sea; indication for a strongly variable geomagnetic field. International Journal of Earth Sciences 88, $116-131$.

Nowaczyk, N.R., Frederichs, T.W., Kassens, H., Norgaard, P.N., Spielhagen, R.F., Stein, R., Weiel, D., 2001. Sedimentation rates in the Makarov Basin, central Arctic Ocean; a paleomagnetic rock magnetic approach. Paleoceanography 16, 368-389.

Pahnke, K., Zahn, R., 2005. Southern Hemisphere water mass conversion linked with North Atlantic climate variability. Science 307, 1741-1746.

Pätzold, J., Cruise Participants, 1999. Report and Preliminary Results of Meteor Cruise M 44/3, Aqaba (Jordan)-Safaga (Egypt)-Duba (Saudi Arabia) - Suez (Egypt) - Haifa (Israel), March 12-March 26-April 2-April 4, 1999. Department of Geosciences, University Bremen, Bremen.

Peltier, W.R., 2004. Global glacial isostasy and the surface of the Ice-Age Earth; the ICE-5G (VM2) model and GRACE. Annual Review of Earth and Planetary Sciences 32, 111-149.

Petoukhov, V., Ganopolski, A., Brovkin, V., Claussen, M., Eliseev, A., Kubatzki, C., Rahmstorf, S., 2000. CLIMBER-2: a climate system model of intermediate complexity, Part I: model description and performance for present climate. Climate Dynamics 16, 1-17.

Rahmstorf, S., 2002. Ocean circulation and climate during the past 120,000 years. In: Nature Insight: Climate \& Water. Macmillan Journals, London, UK, pp. 207-214.

Reimer, P.J., Baillie, M.G.L., Bard, E., Bayliss, A., Beck, J.W., Bertrand, C.J.H., Blackwell, P.G., Buck, C.E., Burr, G.S., Cutler, K.B., Damon, P.E., Edwards, R.L., Fairbanks, R.G., Friedrich, M., Guilderson, T.P., Hogg, A.G., Hughen, K.A., Kromer, B., McCormac, G., Manning, S., Ramsey, C.B., Reimer, R.W., Remmele, S., Southon, J.R., Stuiver, M., Talamo, S., Taylor, F.W., van, d.P.J., Weyhenmeyer, C.E., 2004. IntCal04 terrestrial radiocarbon age calibration, 0-26 cal kyr BP. Radiocarbon 46, 1029-1058.

Roche, D., Paillard, D., Cortijo, E., 2004. Constraints on the duration and freshwater release of Heinrich event 4 through isotope modelling. Nature 432, 379-382.

Rohling, E.J., Marsh, R., Wells, N.C., Siddall, M., Edwards, N.R., 2004. Similar meltwater contributions to glacial sea level changes from Antarctic and northern ice sheets. Nature 430, 1016-1021.

Schmittner, A., Yoshimori, M., Weaver, A.J., 2002. Instability of glacial climate in a model of the ocean-atmosphere-cryosphere system. Science 295, 1489-1493.

Shackleton, N.J., Hall, M.A., Vincent, E., 2000. Phase relationships between millennial-scale events $64,000-24,000$ years ago. Paleoceanography $15,565-569$.

Shackleton, N.J., Fairbanks, R.G., Chiu, T.-C., Parrenin, F., 2004 Absolute calibration of the Greenland time scale: implications for Antarctic time scales and for $\Delta^{14} \mathrm{C}$. Quaternary Science Reviews 23, 1513-1522.

Siddall, M., Rohling, E.J., Almogi, L.A., Hemleben, C., Meischner, D., Schmelzer, I., Smeed, D.A., 2003. Sea-level fluctuations during the last glacial cycle. Nature 423, 853-858.

Skinner, L.C., Shackleton, N.J., Elderfield, H., 2003. Millennial-scale variability of deep-water temperature and $\delta^{18} \mathrm{O}_{\mathrm{dw}}$ indicating deepwater source variations in the Northeast Atlantic, 0-34 cal. ka BP. Geochemistry, Geophysics, Geosystems $-\mathrm{G}^{3}$, doi:10.1029/ 2003 GC000585.

Stoner, J.S., Laj, C., Channell, J.E.T., Kissel, C., 2002. South Atlantic and North Atlantic geomagnetic paleointensity stacks (0-80 ka): implications for inter-hemispheric correlation. Quaternary Science Reviews 21, 1141-1151.

Thompson, W.G., Goldstein, S.L., 2005. Open-system coral ages reveal persistent suborbital sea-level cycles. Science 308, 401-404. 
Vidal, L., Labeyrie, L., Cortijo, E., Arnold, M., Duplessy, J.C., Michel, E., Becque, S., van Weering, T.C.E., 1997. Evidence for changes in the North Atlantic Deep Water linked to meltwater surges during the Heinrich events. Earth and Planetary Science Letters 146, 13-27.

Voelker, A.H.L., Grootes, P.M., Nadeau, M.J., Sarnthein, M., 2000. Radiocarbon levels in the Iceland Sea from $25-53 \mathrm{kyr}$ and their link to the Earth's magnetic field intensity. Radiocarbon 42, 437-452.

von Gyldenfeldt, A.-B., 1999. Modelling the recent and glacial oceanography of the Red Sea. Ph.D. Thesis, Tübinger Mikropaläontologische Mitteilungen 19, 106pp.
Werner, F., Lange, K., 1975. A bathymetric survey of the sill area between the Red Sea and the Gulf of Aden. Geologisches Jahrbuch Reihe D: Mineralogie, Petrographie, Geochemie, Lagerstaettenkunde 13, $125-130$.

Woelk, S., Quadfasel, D., 1996. Renewal of deep water in the Red Sea during 1982-1987. Journal of Geophysical Research-Oceans 101, 18155-18165.

Zweck, C., Huybrechts, P., 2005. Modeling of the northern hemisphere ice sheets during the last glacial cycle and glaciological sensitivity. Journal of Geophysical Research 110, doi:10.1029/2004JD005489. 